\title{
Life Cycle in Natural Populations of Canna indica L. from Argentina
}

\author{
María de las Mercedes Ciciarelli \\ Laboratorio de Estudios de Anatomía Vegetal Evolutiva y Sistemática (LEAVES), \\ Facultad de Ciencias Naturales y Museo, Universidad Nacional de La Plata, \\ Argentina
}

\section{Introduction}

Several species of genus Canna L. (Cannaceae-Zingiberales) from Argentina, such as C. ascendens Ciciarelli, C. coccinea Mill., C. glauca L., C. indica L., C. fuchsina Ciciarelli and C.variegatifolia Ciciarelli were observed to grow mainly by vegetative multiplication of underground rhizomes (Ciciarelli, 1989, 1995, 2007, Ciciarelli \& Rolleri 2008, 2010). For a long time, rhizomes have been considered as the most important propagation mode of many weeds to ensure plant growth and genetic uniformity. Some species, such as $C$. indica, are particularly invasive and even become weeds. This occurs both in the wild and urban areas of several tropical or subtropical American and Asian countries, precisely because of the ease of vegetative propagation through its rhizomes (Maas Van de Kamer \& Maas, 2010; Tanaka 2001). Indeed, extensive populations are formed mostly by vegetative multiplication of rhizomes in Province of Buenos Aires, Argentina (Ciciarelli \& Rolleri, 2008). Field work carried out during several seasons (2003-2011) demonstrated that, after removal of plant populations by human action, seeds germinate easily in the substrate assisted by external factors such as sun radiation, dew and rainfall distributed throughout the year.

This work aims at contributing with knowledge of the life cycle of some herbaceous geophytes such as species of the genus Canna, and with studies of the reproductive mechanisms (sexual or asexual) prevailing throughout several seasons. The present research also includes morphological and histochemical studies of rhizomes and seeds to understand underlying growth factors such as energy, water availability, and resistance to cold. Finally, germination of $C$. indica seeds under natural and in vitro conditions is studied to make a contribution to the understanding of this process in species bearing very hard seedcoats.

Although all species of the genus Canna mentioned above were studied in their phenology and life cycle, this analysis will focus mainly in C. indica: its wide distribution, resistance to eradication by human action, ability to reach a rapid coverage, capacity to cover new fields with dense colonies, to produce many flowers, fruits, and to have seeds with high and quick germination, make this species an interesting example of the characteristics of a typical weed.

Canna indica is a plant of tropical or subtropical origin in South America, distributed over a vast area, reaching southern regions as Province of Buenos Aires (PBA) in Argentina (35 south latitude). In this area, climate is temperate, soils are rich in humus, and the short 

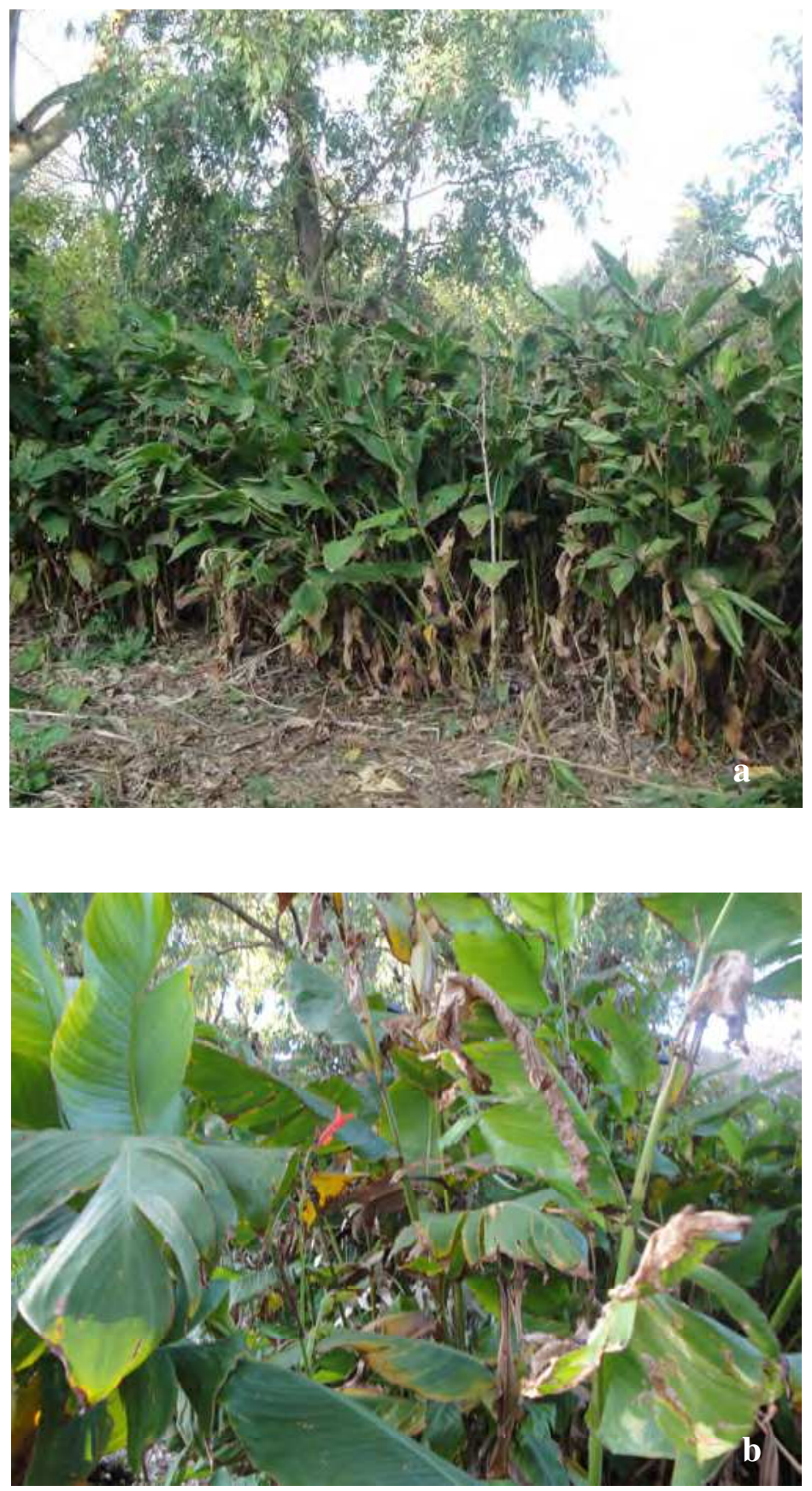

Fig. 1. (a) Canna indica colony (in May, autumn ). (b) Detail of leaves and flowers in the same colony. 
periods of winter frost may constitute a threat for populations. Winter frost may begin in May, and continue over June, July and August causing decay in the aerial parts of the plant until September-October, when they begin to recover. (Fig. 1a, b)

\subsection{Description of the species}

Canna indica L. Sp.Pl.1, 1753, is a mesophyte colonial terrestrial plant 2.5m height. Rhizomes are sympodial underground, with chestnut- brown cataphylls and abundant adaxial and abaxial roots. The aerial shoots are 1-3 cm diameter, with $7-11$ sheathing leaves, patent to reflexed the inferior, ascending the superiors, and sometimes convolutes. The phyllotaxis is distichuous to spirally, and foliar sheaths are light green. Leaves are glabrous, green yellowish, adaxially fasciate, and abaxially greyish green and dull. The contour of leaves is narrow ovate with a length/ width ratio of 2:1. The third leaf is 19-37 (55) cm in length $x 10-$ 18 (30) cm wide. The apices are acute, acuminate, twisted and mostly dry at the tops, with cuneate decurrent asymmetric bases. Venation is eucamptodrome. Primary vein and foliar margins are colourless, with light green foliar sheaths and bracts. Inflorescences are politelicae, intermediate, of $40-41 \mathrm{~cm}$ in length carrying 1-2 paracladia, each one bearing 1-4 nodes, each node carrying 2 flowers. The principal florescence carries 6-8 nodes and the basal internode is of 16-17 cm long. Flowers with 11-12 pieces are $7 \mathrm{~cm}$ long, concolours red or yellow or bicolorous, bright light red at the base and yellow in the third basal part. The floral tube is $3-4 \mathrm{~cm}$ long. The ovarium is inferior and green. Pollen grains are spherical or subspherical 38-61-(63) $\mu \mathrm{m}$, equinatae, spinules conical of $3 \times 3 \mu \mathrm{m}$. Capsules are spherical, subespherical, green of 2-3 x 2-4 cm. Capsules have 20-28 seeds, ovoid in shape, dark chestnut-brown or black in colour, and of 0,5-0,7 cm diameter.

\subsection{Materials and methods}

Populations were observed in situ to study the life cycle and phenology. Field trips were carried out over the years 2003 to 2010, from September (spring in the Southern hemisphere) to June (winter), to observe flowering and pollination processes, fruit and seed production, autumn decay of green parts and the initial emergence of new plants in each colony. Specimens were also collected and cultivated; original plants were grown from rhizomes in an experimental plot and similar observations were conducted. Rhizome branching was studied in the field, carefully digging areas of $2 \mathrm{~m}^{2}$, previously removing green vegetative parts. The rhizomes can be studied throughout the year, but the better period is late winter, before the emergence of aerial stems. Parts of rhizomes were planted again and successive visits during the phenological study showed a rapid recovery. The terms used in describing rhizome branching were taken from Font Quer (1982). For germination in vitro, the seeds collected were briefly immersed in boiling water for three times then were placed in a petri dish and covered with wet cotton.

For studies of the internal morphology of rhizomes, fresh material was fixed in FAA (Johanssen, 1940). Permanent and non permanent samples of longitudinal and transverse sections of adult rhizomes were prepared. Permanent samples were coloured by safraninefast green $2 \%$ in methyl cellosolve and mounted in Canada balsam. Characterization tests were carried out to detect the presence of mucilage (Bismarck Brown) tannins (Ferrous sulphate), and starch (iodine) (Johanssen, 1940). For MEB observations, samples of 
parenchymatous tissue were scrapped and placed on a double face adhesive tape, metalized with gold-palladium and examined with a JEOL JSM T-1100, from the Electronic Microscopy Service of the Facultad de Ciencias Naturales y Museo de La Plata.

\subsection{Key results}

Germination in vitro took about 18 days to produce a new independent plant. Immediately after contacting the boiling water, the seed imbibition lid was expelled and the coat began to soften. At the $3^{\text {rd }}$ day the white cotyledon appeared and pushed the radicle through the micropilar region. At the 7 th day, the white cotyledon, $2.5 \mathrm{~cm}$ long, was observed with the cotyledon node, a short hipocotyle and the tiny radicle. Inside the seed, part of the cotyledon remains in contact with the endosperm with haustorial functions, such as solubilizing, translocating and storing nutrients through the cotyledon towards the growing point.

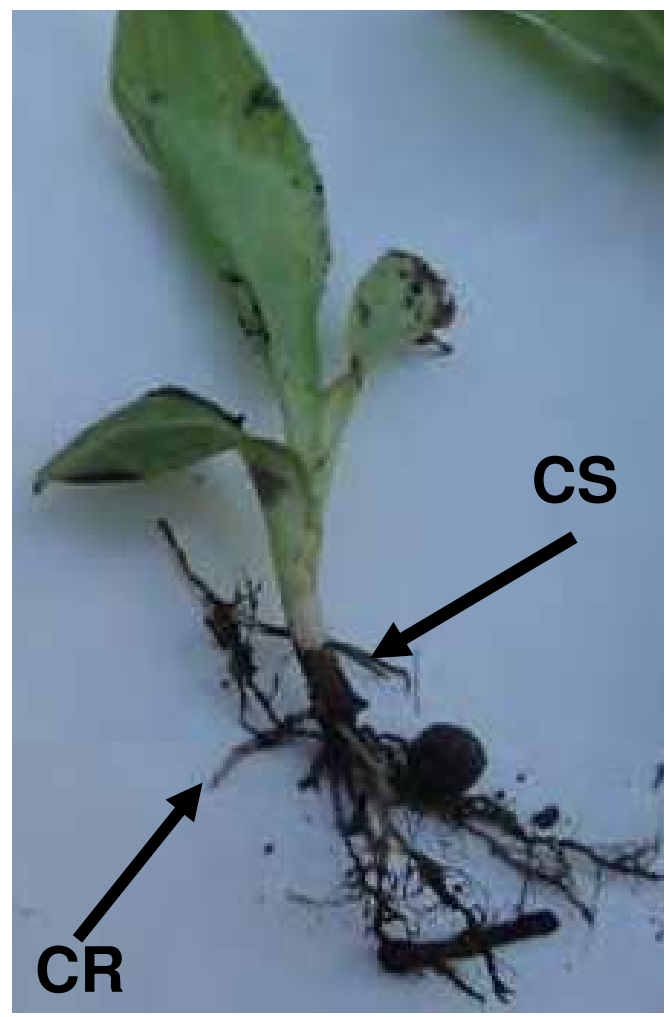

Fig. 2. Seedlings of $C$. indica. CS, cotyledon sheath; CR, collar root.

At the $9^{\text {th }}$ day the positive geotropism of the cotyledon makes it to curve forming the cotyledon knee and directing the primary root towards the earth. The hypocotile is short and bears many endogenous collar roots and a short radicle at the top. 
At the $18^{\text {th }}$ day, the resulting axis is $6 \mathrm{~cm}$ long, with the growing apex being protected by the cotyledon sheath. The first green leaf appears at the top end of the sheath (before the first leaves reaches daylight, the plantlet had been nourished from the seed). The photosynthetic process starts as well as the independent life of the plant. At this time, several white ramifications are observed in the radicle, as described by Tillich (1959). Seedlings are composed of three primary leaves, the cotyledon with the haustorial part and the tubular cotyledon sheath. The hipocotyle, with endogenously shoot-borne roots, and the collar with several endogenous roots. The primary root has exogenous, short root hairs (Fig. 2).

Germination in the field was observed in a small wetland of the area under study. An adult colony of Canna indica completely cut down by human action, had been associated with other herbaceous plants as Typha latifolia, Iris pseudoachorus, Verbena intermedia and Acmella decumbens. After the complete removal of plants a black and humid soil was exposed, and seedlings of Canna indica took about two weeks to appear again. Seedlings were carefully removed from the soil to confirm that they had grown from seeds (Fig. 3). No other species grew there until that moment.

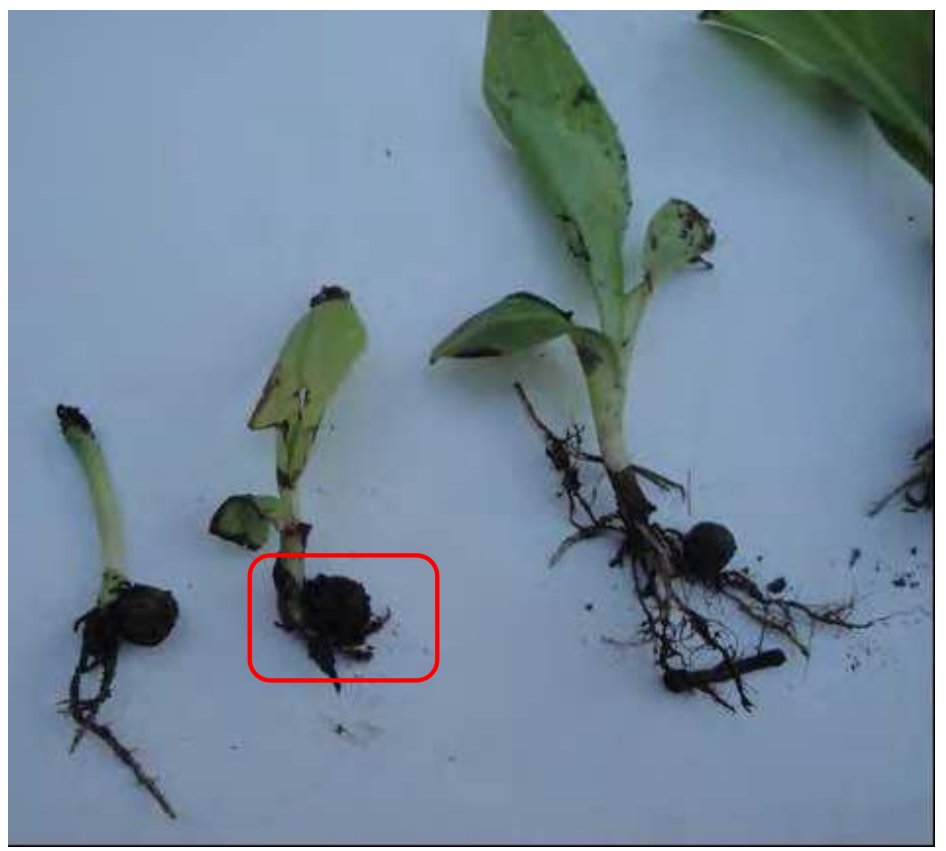

Fig. 3. Seedlings of C. indica. Seed $(0.6-0.8 \mathrm{~cm}$ in diameter) is indicated in a frame.

\subsection{Life cycle in C. indica}

The life cycle of $C$. indica and other species of Canna is of about 9 months. It begins in the first week of September when buds from underground rhizomes start to produce the first green leaves, while aerial foliage of the previous year is completely dry. 

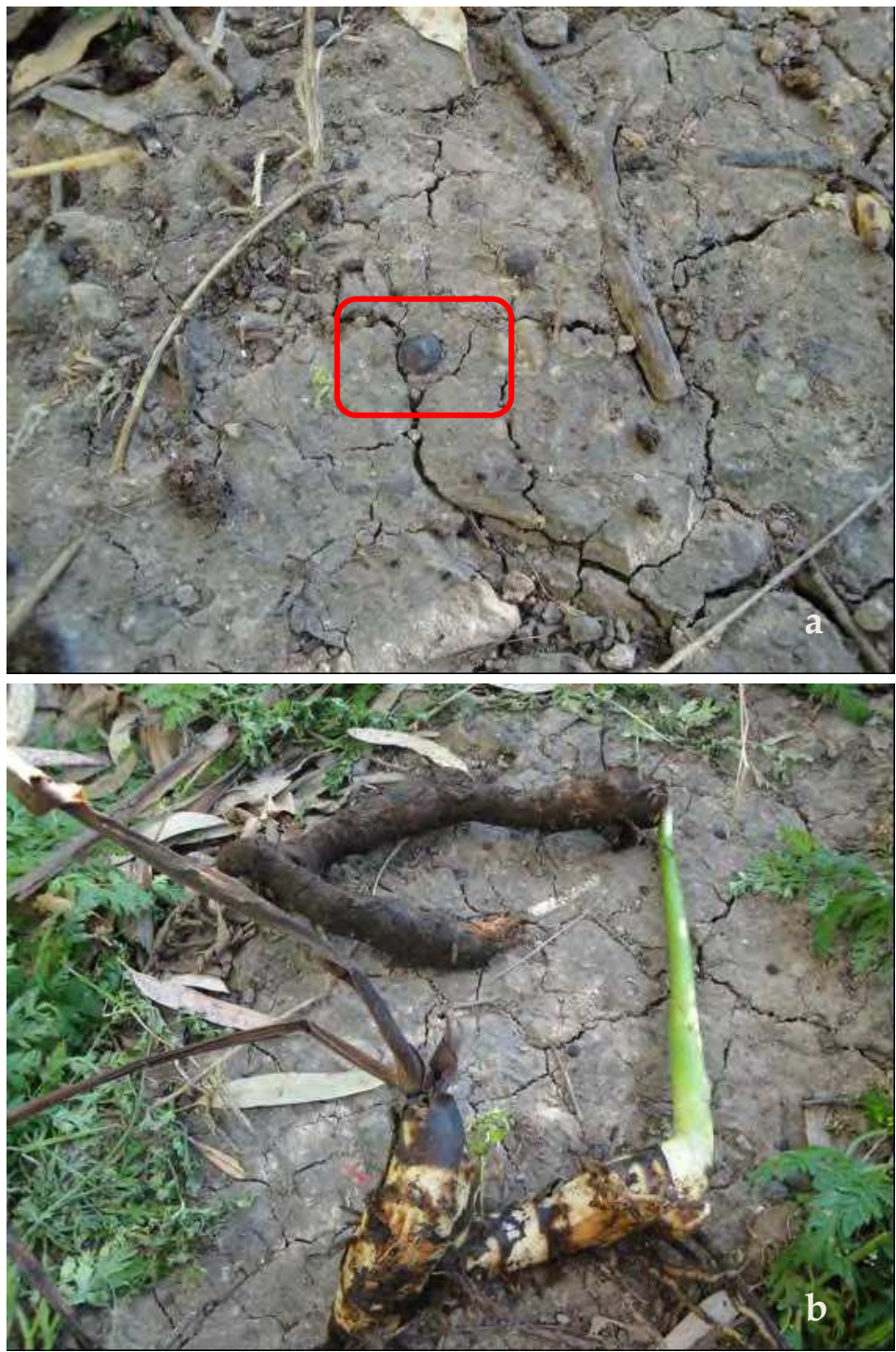

Fig. 4. (a) Seeds of C. indica in the soil (one is framed).

(b) unburied parts of rhizomes, one dried, the other growing.

The weather conditions in La Plata, in Province of Buenos Aires during the first ten days of September are the following: rainfall, $54 \mathrm{~mm}$; mean average temperature, $13.7^{\circ} \mathrm{C}$ (with average minimum of $9,2^{\circ} \mathrm{C}$ and average maximum temperature is of $18,2^{\circ} \mathrm{C}$ ). The average relative humidity in this month is of $79 \%$, with 11.8 hours of solar radiation (Servicio Meteorológico Nacional, 2011; (National Weather Forecast Service)). At the second week of September plants have 2 or three leaves and continue growing along 45 days to reach 
their adult length $(2,5 \mathrm{~m})$ and 7 to 11 leaves. Thus vegetative grow from underground rhizomes takes place from the beginning of September to the end of October. Blooming begins in late October- early November and continues until the end of May in late Autumn. During summer, and particularly at the end of February, colonies reach their maximum size and plants exhibit abundant fruits and seeds. In C. indica one infrutescence carries about 5-6 capsules, each bearing 4-7 seeds, so 20-28 seeds are produced in one infrutescence of the plant. Considering the whole colony, the average number of seeds in C. indica is relevant and greater than in other wild species of Canna growing in the Province of Buenos Aires. Infrutescences of other species of Canna produce the following average number of seeds: C. ascendens, 1-3; C. coccinea, 6-8; C. fuchsina 6-10; C. glauca 6-9 and C. variegatifolia, 3-6.

During the 6 months of Summer and Autumn seeds are abundantly produced and fall to the ground remaining there or else germinating if conditions are adequate. In 2011 the first frost ( May 6 th) produced a slight damage in some flowers. On May 26th, after a second frost, some upper leaves, tops of inflorescences and flowers were dried. On June 2nd the vegetative part of plants was completely dried though some flowers still remained fresh. On the 26 th of June the last flowers were completely frozen. During Winter dried plants and fallen seeds remain on the ground. (Fig. 4a).

It was observed that over the last three years, the life cycle of $C$. indica has been extended one additional month as well as the size of colonies in the field.

\section{Rhizomes}

\subsection{External morphology}

Rhizomes may be monopodial or sympodial, stoloniferous or tuberous according to the species. Concerning $C$. indica, the most vigorous species growing in this area, rhizomes are sympodial with Y-shaped axes (Ciciarelli \& Rolleri, 2008) and abundant roots growing both adaxially and abaxially from the nodes. Monopodial or stoloniferous rhizomes are less common than the other types and are observed in C. glauca and C. variegatifolia, while sympodial types are observed in the other species. Tuberous rhizomes only appear in $C$. coccinea, and in spite of their diverse external morphology, all species of Canna store abundant starch granules.

In C. indica, the rhizome is sympodial, and the plagiotropic axis after producing 5-6 nodes, curves its direction upwards to form the aerial plant. From the base of the last node an axillary bud restarts propagation by repeating the pattern. These "active" nodes can also produce up to three aerial branches, so three new plants grow very close to each other. From the base of those active nodes, abaxial and adaxial roots are abundant. By repeating this growth mecanism, one row of plants can be formed. Besides, the main axis can also divide into two other branches forming a " $\mathrm{Y}$ " branching mode, so other 2 rows of plants are produced parallel to the previous row. " $Y$ " branching propagation of the rhizome increases not only the number of plants but also the underground connection among them, occupying a wider soil surface. This pattern is usually disordered and crossover of branches coming from different axes may occur. This branching system is similar to that of Alpinia speciosa (Bell, 1979). (Fig. 4b, 5a). 

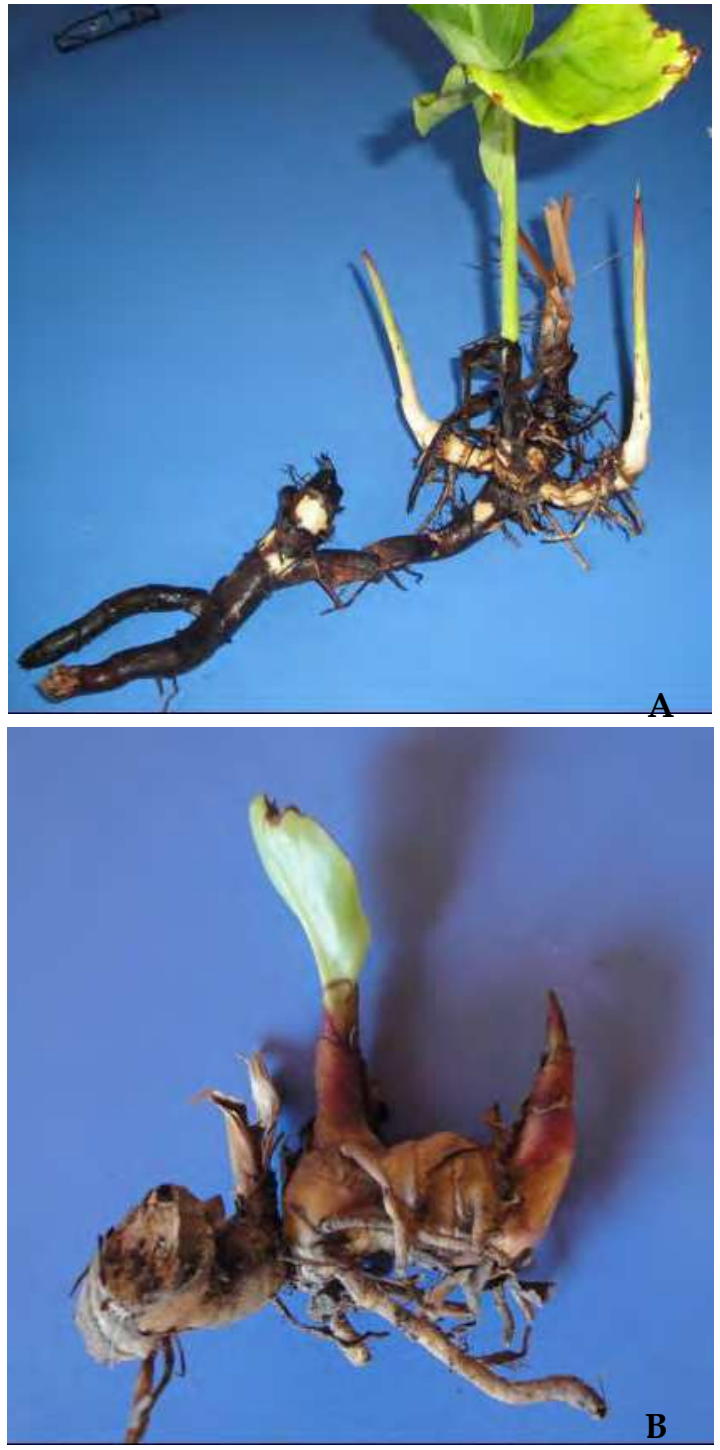

Fig. 5. (a) Simpodial rhizome of C.indica. "Y" ramification, and 3 aerial branches.

(b) Early development of simpodial rhizome in C. fuchsina

\subsection{Internal morphology}

The rhizome of Canna, as seen in transverse section, has the following organization: epidermis, hypodermis, cortex, endodermis, pericycle, vascular plexus and central cylinder. In all species the epidermis cell walls are scarcely cutinized. Beneath the epidermis there is a three layered hypodermis, which exhibits cells with subpolygonal outline and thickened walls. The cortex is a relatively thin zone placed between the hypodermis and the 
endodermis. It is mainly composed by a parenchymatous tissue, which store abundant starch granules and tanniferous contents. It also reveals an outer ring of fibrous strands, many internally spread fibrovascular strands as well as foliar and root traces. In the palustrine species of $C$. glauca, schyzogenous lacunae are also observed in the cortex. One endodermal layer may be present as a continuous ring in C. ascendens, C. coccinea, C. glauca, C. indica and C. variegatifolia or as several arcs separated by parenchymatous tissue in $C$. coccinea and C. compacta. In the former species a well defined cortex is observed and most endodermal cells present Casparian bands. In C. compacta the thickening of the cell walls is complete or in "O". A pericycle is always evident and presents one layer of cells. It surrounds a zone composed of close and anastomosing vascular strands with many xylem vessels. These are disposed between parenchymatous cells, some with tanniferous contents. The presence of abundant xylem elements in this zone of the rhizome is related to the production of root and cataphylls traces. According to Tomlinson (1962) this zone is called "vascular plexus", and is quoted for rhizomes of families belonging to the Order Scitaminae.
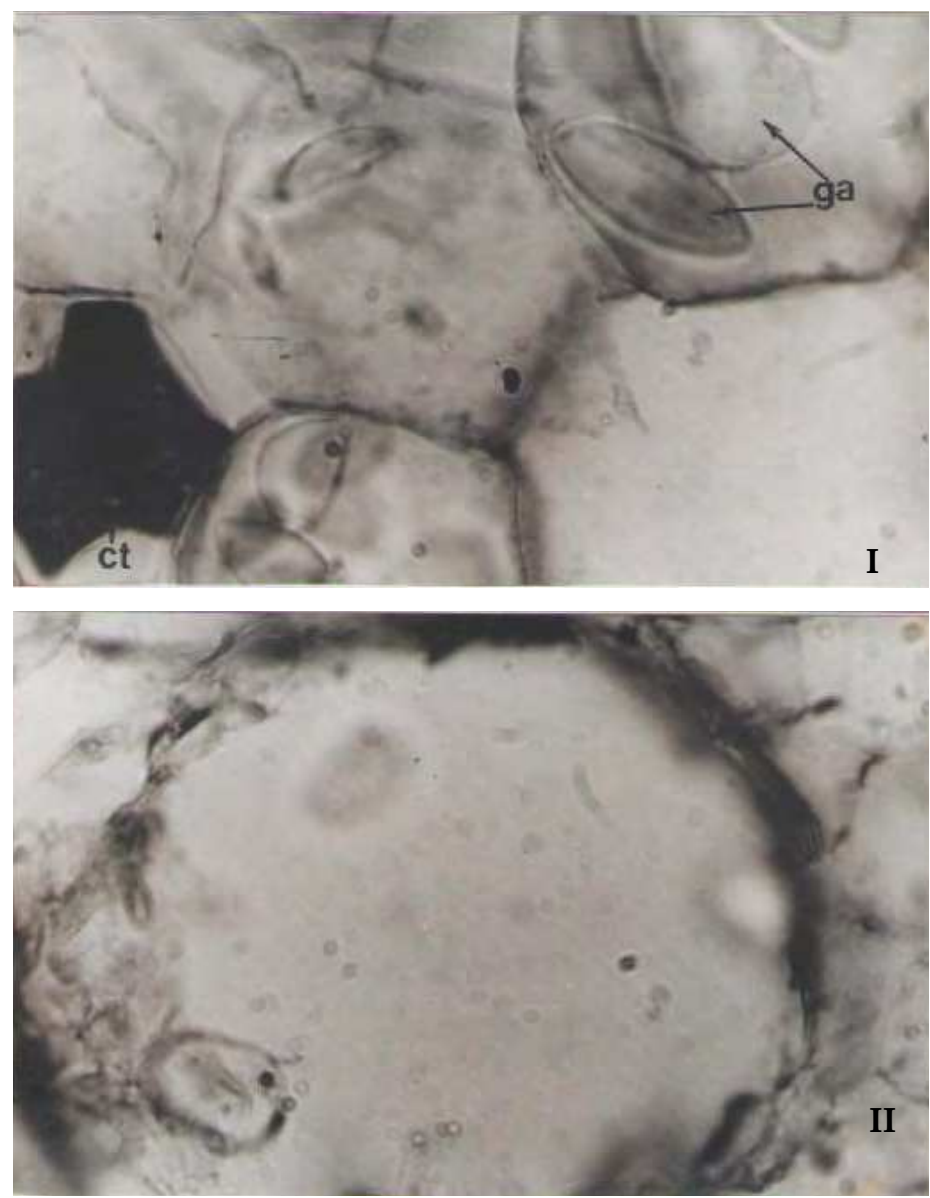

Fig. 6. (a) Central cylinder in C. glauca. I. starch granules (ga) and tanniferous cells (ct). II. Mucilage duct. Black bars represent $100 \mu \mathrm{m}$ 
The central cylinder presents a parenchymatuous tissue specialized in storage of ovoidal and excentric starch granules, and other substances as tannins, and prismatic crystals of calcium oxalate (fig. 6a, I). Fibro-vascular and collateral bundles are irregularly scattered in the cylinder. In C. glauca, each one bears 1-2 metaxylem elements and phloem, adaxially and abaxially surrounded by fibres. In the other species the bundles are bigger in size and have more metaxylem elements, until 10 as in C. coccinea. Mucilage ducts, are regularly distributed in the central cylinder, they have a circular outline in C. glauca (fig. 6b, II ) and ellipsoidal in the other species.

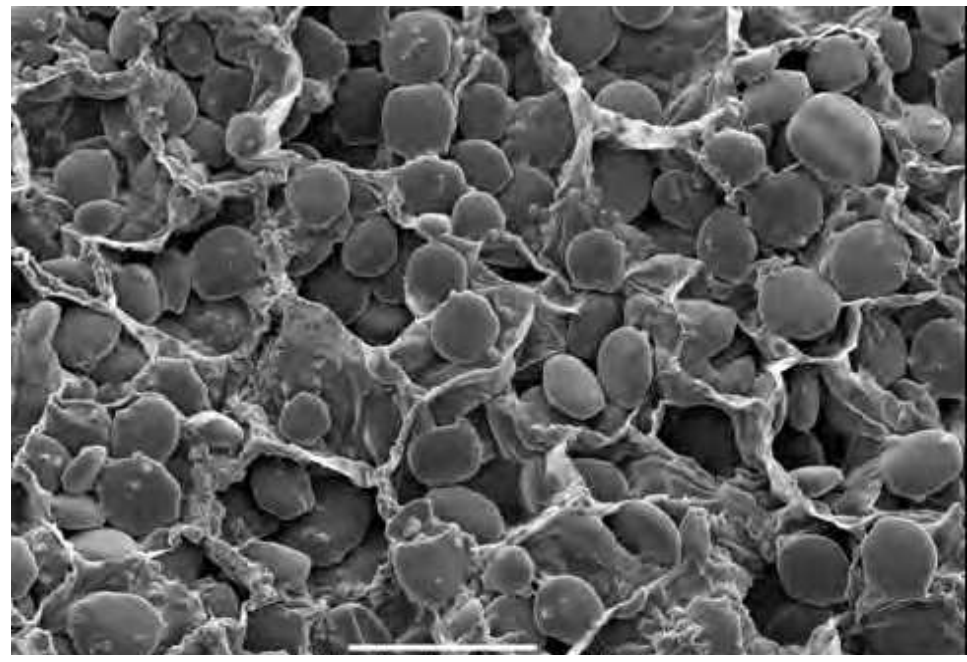

Fig. 6. (b) Scanning electron micrograph of starch granules and calcium oxalate crystals in Canna sp. The white bar at the bottom represents $100 \mu \mathrm{m}$

In C. glauca, the central cylinder bears an aerenchyma with large cells, surrounding the lacunae. Many cells of this tissue also contain starch granules. Aerenchyma is not present in other species, and there are other differences in shape and size of mucilage ducts. C. coccinea and C. compacta have elliptical mucilage ducts, not circular as in the other species.

\section{Seeds}

Seeds are regularly produced in all species and strewn out of the capsule when moved by the wind or touched by passing animals. The production of seeds is different in each species of Canna. Thus, C. indica presents 20-28 seeds, C. coccinea 6-8 seeds, C. variegatifolia 3-6, C. ascendens 1-3, C. glauca 6-12, and C. fuchsina 6-10. Seeds initially white and when mature, black or black, with chestnut brown spots are protected with a smooth coat. In C. indica, $C$. ascendens and $C$. variegatifolia, seeds are spheroidal, black, small $(0.6$ to $0.8 \mathrm{~cm})$. In turn, seeds are spheroidal black and larger $(1-1.2 \mathrm{~cm})$ in C. coccinea and C. compacta, while they are ellipsoidal and black, spotted of chestnut brown, 0,5- 0,9 cm in size, for C. glauca.

Seed microstructure consists of a massive chalaza, surrounded by an extremely hard, completely impermeable seedcoat. No germination is possible under normal conditions of 
temperature and humidity, because the seed cannot absorb water, therefore, it does not swell, remaining hard. The embryo is linear and bears one large cotyledon and a tiny plumule and rootlet.

According to Grootjen \& Bouman (1988), the seed coat is mostly formed by chalaza tissue and in a lower proportion of integumentary and raphal tissue.

The chalazal part of the seed coat consists of four layers: the exotesta which is formed by the epidermis, and the three-layered endotesta.

The epidermis is composed by a palisade layer of long and narrow cells with very thickened walls called "Malphigian cells" : in them, Graven et al. (1996) recognise two zones, the lower hydrophilic and the upper hydrophobic. The first zone is mainly composed by cellulose, while the upper one contains silica, callose, and lignin. In Cannaceae the epidermis becomes the seed exotesta.

The endotesta comprises three layers of chalazal origin: the subepidermal, the vascularized as well as the "tanniferous". In the latter layer, polyphenols are abundant cell contents, which are considered to impart a secondary dormancy after shedding of the seed imbibition lid (Graven et al. 1997).

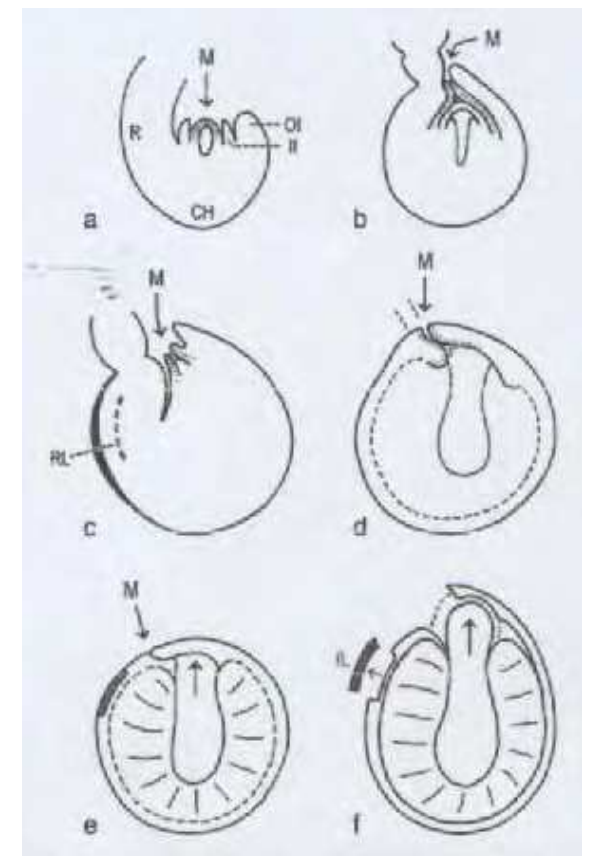

Fig. 7. Details of developing ovule and seed $(\mathrm{CH}=$ chalazal tissue, $\mathrm{II}=$ inner integument; $\mathrm{IL}=$ imbibition lid; $\mathrm{M}=$ micropyle; $\mathrm{OI}=$ outer integument; $\mathrm{R}=$ raphal tissue; $\mathrm{RL}=$ rupture layer.) $\mathrm{a}$. Longitudinal section of developing ovule; b.Mature ovule; c.Developing seed showing rupture layer; d.Developing seed with vestigial micropylar collar; e. Mature seed, showing imbibition lid; F.Germinating seed after shedding of imbibition lid (After Grootjen \& Bouman 1988). 
Integumentary tissue: the area around the micropyle and the micropyle itself (which represents only about $1 / 15$ th part of the seedcoat surface) is formed by the inner integument (Fig.7, a, II). The integumentary seed coat is similarly composed of 4 layers: epidermis or palisade layer, subepidermal, vascularized, and tanniferous layer. The subepidermal layer grows inwards around the apex of the embryonal root, to form a small micropylar collar (Fig.7 d).

Raphal tissue: the raphal part of the seed coat form an 'imbibition lid' of 1.5-3 mm diameter. At the beginning of the imbibition process, the only visible part of the seed coat is an elevated circular area devoid of stomata close to the hilar-micropylar slit. As a consecuence of hydration the more or less circular boundaries surrounding the lid area loosen and the lid is expelled (Fig. 7c, RL). The lid itself is composed of only the two outer layers of the seed coat, the exotesta, and the lowermost subepidermal layer of endotesta which both constitutes the rupture layer. It is suggested that during imbibition, a difference in pressure between the hydrophylic and hydrophobic parts of the Malpighian cells is developed in the exotesta. This effect induces shedding of the lid along the rupture layer (Fig. 7 e, f). Graven et al.(1997) have found that the mechanism activating the opening of the imbibition lid is an elevated incubation temperature of $50^{\circ} \mathrm{C}$ during 24 hours in wet surroundings.

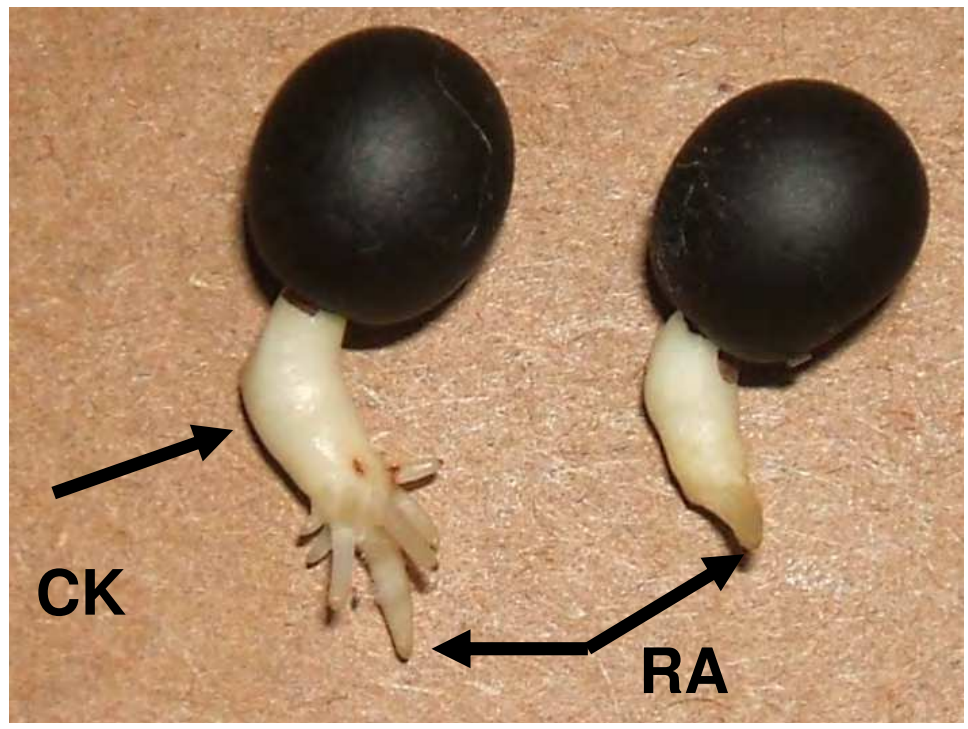

Fig. 8. (a) C. indica seeds after 7 days of germination. $C K=$ cotyledon knee; $R A=$ radicle.

Ciciarelli (2011) observed that germination, as well as the production of leafs from rhizome in the field, start in the beginning of September. Weather conditions at that time are an average temperature is of $13,7^{\circ} \mathrm{C}$, and average relative humidity of $79 \%$ and $54 \mathrm{~mm}$ average of rainfall monthly. Seeds germinate under natural conditions when placed in a moist, airy, free and humiferous soil. A daily sun radiation of $11,8 \mathrm{~h}$ and maximum temperatures up to $18,2{ }^{\circ} \mathrm{C}$ produces the necessary temperature raise that allows the shedding of the lid. Minimum average of temperature registered for the month of $9,2{ }^{\circ} \mathrm{C}$, 
does not avoid germination once initiated. This last observation coincides with the opinion of Cooke (2001). Following this, hydration and translocation of water inside the seed are possible, especially through the vascularized layer of the inner integumentary in direction to the endosperm, where enzymatic reactions triggers germination, later allowing the emergence of the cotyledon-radicle from the seed (Fig. 8a).

In Cannaceae the main mechanical properties of hardness and also the lid shedding mecanism through the rupture layer are provided mainly by the exotesta. The secondary dormancy is related to the tanniferous layer of the endotesta and the hydration and translocation of water is through the vascularized layer of endotesta.

In horticulture, and in vitro conditions the imbibition lid is removed deliberately to make germination possible.

This extremely hard coat and its indirect hydration mechanism allowed seeds of Canna compacta from the North West of Argentina to protect germ during 600 years under dry conditions (Sivori et al. 1968). After being brought to the laboratory one of the seeds germinated by scarification of the seed coat, growing a plant that bloomed and produced fruits and seeds.

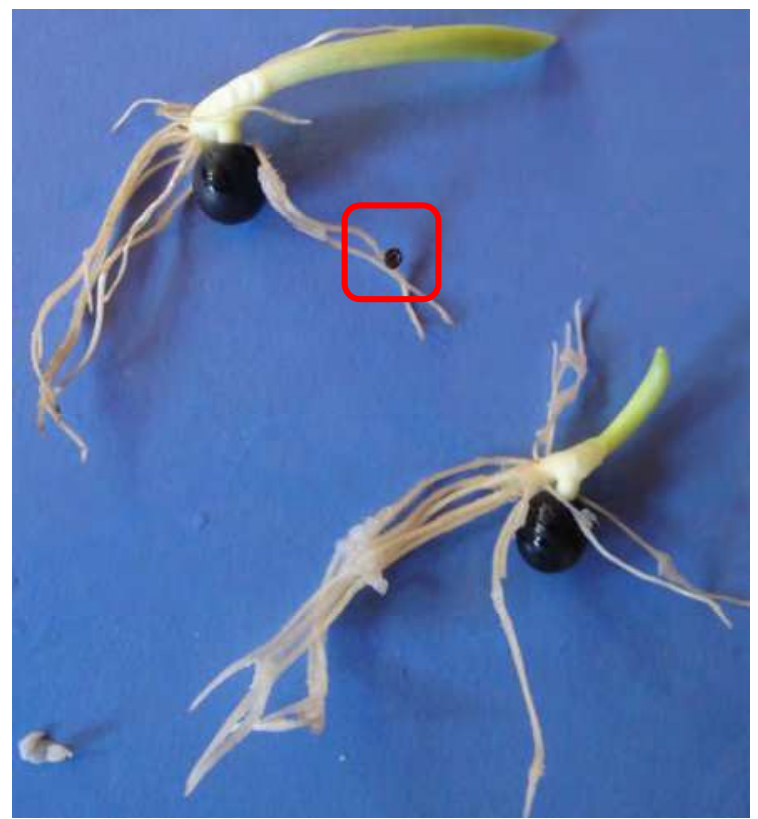

Fig. 8. (b) C. indica seedlings after 18 days of germination in vitro. The imbibition lid (framed) is shown.

\section{Discussion and conclusions}

The external morphology of the simpodial rhizome shows a very invasive "Y"-branching way of propagation similar to those of other colonial species as Alpinia speciosa (Zingiberaceae), as 
well as other species of Canna. In Cannaceae, C. indica produces the largest colonies in the Buenos Aires region.

The most important features of the internal morphology of rhizomes are the presence of parenchyma with abundant starch granules, as well as mucilage ducts, calcium oxalate crystals, and tanniferous cells. It is suggested that tannins may provide impermeability in plants. In Cannaceae these substances are stored in cells of rhizomes, stems and leaves, and may provide cold resistance in rhizomes, and,according to Graven et al. (1996), a secondary dormancy in seeds. Mucilages have always been related to the storage and availability of water in plants. In Cannaceae (Ciciarelli,1989) these substances are visible in circular or ellipsoidal ducts of longitudinal and transverse sections of rhizomes, stems and inflorescences supposedly related to maintain internal moisture in plants as well as the functions mentioned above. Abundant starch granules provide the nutritious source of energy for cell division and growth.

The presence of starch in species of Canna has been very important as a source of food for many cultures of the Peruvian Andes (Gade, 1966), in other regions of South America and Mexico. Rhizomes are cultivated and eaten in China, Vietnam and Japan, among other asian countries. (Tanaka, 2001, 2004, 2006).

Concerning the life cycle, if plants are not removed, the colonies will increase very much in size, due to asexual reproduction. The substrate is fully occupied by the growing colony and there are no room for seeds to grow from the soil, and, therefore, no seedlings are observed under adult plants. However, if part or the whole colony is cut down, and the substrate becomes exposed, fallen seeds from the progenitors are able to naturally grow. Weather conditions at the beginning of September in La Plata ( PBA) are adequate for the growth of leaves from underground rhizomes as well as the germination of seeds in the field. In the first ten days, warm temperatures were from $14-18{ }^{\circ} \mathrm{C}$, high average relative humidity of $80 \%$ and rainfall of $54 \mathrm{~mm}$. The humiferous, airy and fertile soil has to be cleared from other plants to allow seeds to germinate. Sun radiation of $11,8 \mathrm{~h}$ daily and warm temperatures with a water intake from rain and dew triggers the germination mechanism described above and posibilitates plant growth. Seedlings with two leaves arising from seeds are visible in one or two weeks in this region (Fig. 3 ). Germination "in vitro" took about 18 days to produce a seedling with 2 leaves ( Fig 8 B).

Seedlings were not observed in the surroundings of old colonies in PBA, but seeds remain in the soil under their progenitors. No germination was observed under adult plants, but in the boundaries, where the soil was free from plants, seeds can naturally grow.

This situation is similar to that of forests of Sequoia sp in North America where a large colony of trees were produced from the neck of the roots (Jepson, 1923). When an old tree dies, buds from roots produce trees scattered in a circle surrounding the original stum. Sequoias are known to live up to 1300 years (Jepson, 1923). The author estimates that in such a forest the $80 \%$ of adult trees were produced by asexual reproduction while the remaining $20 \%$ by seed germination. In the central part of the forest, reproduction is almost exclusively by buds, while seedlings settle down in open and peripheral zones (Grant, 1989).

Some traits of Canna indica colonies as the remarkable height of plants, profuse seeds production, rapid growth, abundant descendants in adult colonies are, from an ecological 
point of view, typical of an r-strategist. Descendants can be quickly produced from seedlings in 1 to 3 weeks. If plants are young when frosts kill them, small rhizomes may survive underground until the following spring.

In Canna, seeds may represent a long term genetic reservoir that fell naturally from dried and opened fruits and remain in the ground or elsewhere. If the progenitors die, or the colony is destroyed by biotic or abiotic factors, or even remain in a very dried place, seeds are able to produce a new generation of plants with different genotypes from that of the original colony. This hypothesis has been confirmed in C. compacta, a species from the north west of Argentina, in which hard seedcoats are known to protect germ for centuries under dry conditions (Sivori et al.1968). However, when brought into the laboratory one of the seeds germinated, producing a plant that bloomed and produced fruits and seeds. Seedcoat hardness, extreme longevity, a water absorption-regulating mechanism consisting of an impermeable palisade layer and an imbibition lid are seed features that favor the insertion of the genotype in the environment.

The genetic variability provided by sexual reproduction (seeds) may be useful to colonize a new environment, or cleared soil after cutting part of the original population.

Rhizomes may represent a short term genetic reservoir, safer and faster, it remains underground, and in spring, axillary buds start growing and continue the production of plants until June, resulting in a uniclonal colony. However, at the end of June (winter) seeds that fell from capsules remain in the ground, and if conditions are adequate as those described above, new genetically different clones can grow from seedlings and enrich the genetic reservoir of the colonies, and most importantly, of the species. Cross pollination between different colonies may occur, and provide an explanation for such a variability in several morphological traits, particularly flowers in this species. The variation in number, pattern of colour of staminodes and labella were characters utilized by authors to describe several varieties under the name of $C$. indica; for instance, Tanaka (2001) have described four varieties in Asia.

The phenological studies of colonies in the field may contribute to improve knowledge on the life cycle of the plant, to evaluate the possibilities of cross- pollination between different colonies as well as the production of new viable genotypes from seeds. Phenological studies may also help elucidate taxonomic problems in the Cannaceae familiy which may even become prototype for other families as well.

Possibly as a consequence of global warming, in the last three years colonies were observed to extend their survival period in one month compared with previous years.

This longer life cycle of $C$. indica as a result of warmer seasons contributes to enlarge colonies in the field.

\section{Acknowledgements}

This work was supported by the Facultad de Ciencias Naturales y Museo, Universidad Nacional de La Plata, and was held in the LEAVES, led by Dr. Cristina H. Rolleri, to whom the author wishes to express her thanks for many suggestions and advice. 


\section{References}

Bell A. D. 1979. The hexagonal branching pattern of rhizomes of Alpinia speciosa (Zingiberaceae). Annals of Botany 43 (2): 209-223.

Ciciarelli M. M. 1989. Las Cannaceae Link. Argentina. Tesis Doctoral. Facultad de Ciencias Naturales y Museo de L Plata, Argentina. 246 pags.

Ciciarelli M. M. 1995 Canna variegatifolia Ciciarelli (Cannaceae- Zingiberales), una nueva especie para Argentina. Rev. Museo La Plata, Bot. 14 (103): 333-341

Ciciarelli M.M. 2007. Canna ascendens Ciciarelli (Cannaceae) una nueva especie de la provincia de Buenos Aires y comentarios de otras especies argentinas de este género. Darwiniana 45: 188-200. ISSN 0011-6793. Publicaciones del Instituto de Botánica Darwinion. San Isidro. Argentina.

Ciciarelli M. M. \& Rolleri, C.H. 2008. Morfología, taxonomía y caracterización de siete especies neotropicales del género Canna (Cannaceae- Zingiberales). Botanica Complutensis 32: 157-184.

Ciciarelli M. M., Rolleri, C. H., \& M. C. Gonzalez Dubox. 2010. Canna fuchsina ( CannaceaeZingiberales), una especie nueva para la Argentina y sus relaciones con otras especies del género. Botanica Complutensis 34: 49-55. ISSN 0214-4565. Publicaciones de la Universidad Complutense de Madrid, España. Indexed by SCOPUS.

Cooke, I. 2001. The Gardener's Guide to Growing Canna. Timber Press. ISBN 978-0-88192513-5

Font Quer , P. 1965. Diccionario de Botánica. Ed. Labor, S.A., Barcelona.

Gade, D. W. 1966. Achira, the edible Canna, its cultivation and use in the Peruvias n Andes. Economic Botany 20 (4): 407-415.

Grant, V. 1989. Especiación Vegetal. Noriega Eds. Mexico.

Graven, P.,C. G. de Koster, J.J. Boon \& F. Bouman. 1997. Functional aspects of mature seed coat of the Cannaceae. Pl. Syst. Evol. 205: 223-240.

Grootjen, C.J. \& F. Bouman. 1988. Seed structure in Cannaceae: Taxonomic and ecological implications. Ann. Bot. (Oxford) 61: 363-371, f. 1-4.

Jepson, W. L. 1923 .The trees of California . Associated Students Store. Berkeley. Calif.

Johanssen, W. A. 1940. Plant Michrotechnique. New York.

Maas van de Kamer, H., Maas P.J.M. 2008. The Cannaceae of the World. Blumea.53: 247-318 (72)

Tanaka, N. 2001. Taxonomic revision of the family Cannaceae in the New World and Asia. Makinoa 1: 1- 74.

Tanaka, N. 2004. The utilization of edible Canna plants in southeastern Asia and southern China. Economic Botany 58: 112-114.

Tanaka, N., N. Inouch, and T. Koyama. 2006. Edible canna and its starch: an underexploited starch-producing plant resource. Food \& Food Ingredients Journal of Japan 211: 319-325.

Tillich, H. J. 1959. Seedlings and systematics in Monocotyledons. In: P.J. Rudall, P.J. Cribb, D.F.Cutler \& C.J. Humphries, Monocotyledons: systematics and evolution: 303-352. Royal Botanic Gardens, Kew.

Tomlinson P.B. 1962. Phylogeny of the Scitaminae: morphological and anatomical considerations. Evolution 16: 192-213.

Sivori, E., Nakayama, F. \& Cigliano, E. 1968. Germination of "achira" seed (Canna sp.) approximately 550 years old. Nature 219 (5.160): 1269-1270. 


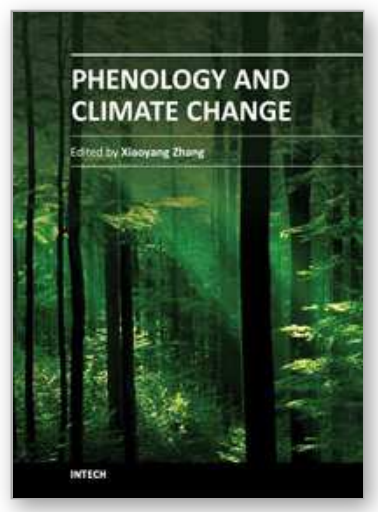

\author{
Phenology and Climate Change \\ Edited by Dr. Xiaoyang Zhang
}

ISBN 978-953-51-0336-3

Hard cover, 320 pages

Publisher InTech

Published online 21, March, 2012

Published in print edition March, 2012

Phenology, a study of animal and plant life cycle, is one of the most obvious and direct phenomena on our planet. The timing of phenological events provides vital information for climate change investigation, natural resource management, carbon sequence analysis, and crop and forest growth monitoring. This book summarizes recent progresses in the understanding of seasonal variation in animals and plants and its correlations to climate variables. With the contributions of phenological scientists worldwide, this book is subdivided into sixteen chapters and sorted in four parts: animal life cycle, plant seasonality, phenology in fruit plants, and remote sensing phenology. The chapters of this book offer a broad overview of phenology observations and climate impacts. Hopefully this book will stimulate further developments in relation to phenology monitoring, modeling and predicting.

\title{
How to reference
}

In order to correctly reference this scholarly work, feel free to copy and paste the following:

María de las Mercedes Ciciarelli (2012). Life Cycle in Natural Populations of Canna indica L. from Argentina, Phenology and Climate Change, Dr. Xiaoyang Zhang (Ed.), ISBN: 978-953-51-0336-3, InTech, Available from: http://www.intechopen.com/books/phenology-and-climate-change/life-cycle-in-natural-argentininianpopulations-of-canna-indica-I-

\section{INTECH}

open science | open minds

\author{
InTech Europe \\ University Campus STeP Ri \\ Slavka Krautzeka 83/A \\ 51000 Rijeka, Croatia \\ Phone: +385 (51) 770447 \\ Fax: +385 (51) 686166 \\ www.intechopen.com
}

\author{
InTech China \\ Unit 405, Office Block, Hotel Equatorial Shanghai \\ No.65, Yan An Road (West), Shanghai, 200040, China \\ 中国上海市延安西路65号上海国际贵都大饭店办公楼 405 单元 \\ Phone: +86-21-62489820 \\ Fax: +86-21-62489821
}


(C) 2012 The Author(s). Licensee IntechOpen. This is an open access article distributed under the terms of the Creative Commons Attribution 3.0 License, which permits unrestricted use, distribution, and reproduction in any medium, provided the original work is properly cited. 